\title{
The effect of intensity-modulated radiotherapy and rectum volume on formation of acute gastrointestinal toxicity in prostate cancer
}

\section{Prostat kanserinde yoğunluk ayarlı radyoterapi ille rektum volümünün akut gastro intestinal toksisite oluşumuna etkisi}

\author{
Ayfer Ay Eren ${ }^{1}$, Mehmet Fuat Eren ${ }^{2}$
}

Radiation Oncology Clinic, Kartal Dr. Lütfi Kırdar City Hospital, Istanbul, Turkey

2 Radiation Oncology Clinic, Marmara University, Pendik Education and Research Hospital, Istanbul, Turkey

Corresponding author: Mehmet Fuat Eren, MD, Radiation Oncology Clinic, Marmara University, Pendik Education and Research Hospital, Istanbul,

Turkey

E-mail: drmehmeteren@gmail.com

Received/Accepted: November 25, 2021 / December 30, 2021

Conflict of interest: There is not a conflict of interest.

\section{SUMMARY}

Objective: High-dose radiotherapy (RT) in prostate cancer has a high local control rate. Generally, the normal tissue toxicity of high doses is overlooked. We aimed to evaluate the rectal volume, diameter, and related dosimetric evaluation that may cause acute gastrointestinal (GIS) side effects in prostate cancer that we treated with intensity-modulated radiotherapy (IMRT).

Method: Seventy-nine patients we treated with definitive or postoperative IMRT were evaluated for acute GIS toxicity according to Radiation Therapy Oncology Group (RTOG) toxicity criteria. The presence of acute GIS side effects and dosimetric parameters including grade and rectal volume and diameter were evaluated.

Results: Seventy-nine patients treated with IMRT were evaluated. Acute GIS toxicity was observed in $21(26.6 \%)$ patients after RT, Grade II side effects were observed in $7(8.8 \%)$, and grade I acute side effects were observed in $14(17.6 \%)$. Grade III and IV toxicity was not observed in any of the cases. No significant correlation was found between the grade of acute GIS side effects and the rectum values of V75, V65, V40, and V30 in dosevolume histograms (DVH), respectively, and rectal volume $(\mathrm{cm} 3)$ and largest diameter $(\mathrm{cm})$ measurements $(\mathrm{p}>0,05)$. The $\mathrm{D}$ median for definitive RT of PTV was $78 \mathrm{~Gy}$, and the D median was $66 \mathrm{~Gy}$ for postoperative RT. No significant correlation was found between the occurrence of acute GIS side effects and grade of definitive or postoperative radiotherapy ( $\mathrm{p}$ values, respectively, $\mathrm{p}=0.693, \mathrm{p}=0.307$ ). No significant correlation was found between the widest rectal diameter of less than $5 \mathrm{~cm}$ in planning and acute GIS side effects and acute GIS side effects Grade I ( $p=0.414, p=0.546)$.

Conclusions: Prostate cancer treatment with IMRT had low rates of acute GIS toxicity. According to our study, the occurrence of acute GIS side effects was independent of rectal volume, diameter, and dosimetric parameters.

Keywords: Prostate IMRT, rectal volume, anterior-posterior rectal diameter, acute GIS side effects
Ayfer Ay Eren

Mehmet Fuat Eren

ORCID IDs of the authors:

A.A.E. 0000-0003-0641-3378

M.F.E. 0000-0002-6531-978X 
ÖZET

Amaç: Prostat kanserinde yüksek doz radyoterapi (RT), yüksek lokal kontrol oranına sahiptir. Genellikle yüksek dozların normal doku toksisitesi göz ardı edilmektedir. Yoğunluk ayarlı radyoterapi (YART) ile tedavi ettiğimiz prostat kanserinde akut gastro intestinal (GíS) yan etki oluşumuna neden olabilecek rektal volüm, çap ve ilişkili dozimetrik değerlendirmeyi amaçladık.

Yöntem: Definitif veya postoperatif YART ile tedavi ettiğimiz 79 hasta akut GíS toksisite açısından Radiation Therapy Oncology Group (RTOG) toksisite kriterlerine göre değerlendirildi. Akut GíS yan etki varlığı ve grad ile rektum volüm ve çapını da içeren dozimetrik parametreler değerlendirildi.

Bulgular: YART ile tedavi edilen 79 hasta değerlendirildi. RT sonrası hastaların 21'inde (\%26.6) akut Gís toksisitesi gözlenmiş olup, 7’sinde grad II (\%8,8), 14'ünde Grad I (\%17.6) akut yan etki gözlendi. Hiç bir olguda grad III ve IV toksisite gözlenmedi. Akut GİS yan etki grad ile doz volüm histogramlarındaki (DVH) rektumun sırasıyla; V75, V65, V40, ve V30 rektum değerleri ile, rektum volüm $\left(\mathrm{cm}^{3}\right)$ ve en geniş çap $(\mathrm{cm})$ ölçümleri arasında anlamlı ilişki bulunamadı (p>0,05). PTV definitif RT için D median 78 Gy, postoperatif RT'de ise D median 66 Gy olarak bulundu. Definitif veya postoperatif radyoterapinin akut GíS yan etki oluşumu ve grad arası anlamlı ilişki bulunamadı ( $p$ değerleri sırası ile $\mathrm{p}=0.693$, $\mathrm{p}=0.307$ ). Planlamada en geniş rektum çapının $5 \mathrm{~cm}$ 'den az olması ile akut GİS yan etki ve akut GíS yan etki grad I arası anlamlı ilişki bulunamadı $(\mathrm{p}=0.414, \mathrm{p}=0.546)$.

Sonuç: YART ile prostat kanseri tedavisi düşük akut GIS toksiste oranlarına sahip olup, akut GíS yan etki oluşumu bizim çalışmamıza göre rektum volümü, çap ve dozimetrik parametrelerden bağımsızdı.

Anahtar sözcükler: Prostat YART, rektal volüm, rektum ön arka çapı, akut GIS yan etki

\section{INTRODUCTION}

Prostate cancer is the most common type of cancer in men, accounting for one-third of all cancers ${ }^{1}$. Radiotherapy (RT) in prostate cancer is one of the main treatment modalities used in primary, postoperative, and salvage treatments. In radiotherapy, over the years, two-dimensional (2DRT) and 3-dimensional conformal radiotherapy (3D-CRT) techniques have been shifted to intensity-modulated radiotherapy (IMRT), in which the surrounding normal tissues are better protected, and even image-guided radiotherapy (IGRT) in which organ movement is followed.

Studies have shown that the desired local control and survival contribution cannot be achieved unless doses of $70 \mathrm{~Gy}$ and above are increased in localized prostate cancer with 3D-CRT and IMRT ${ }^{2-4}$. In some dose-escalation studies, it has been shown that increased treatment doses also increase early and late rectal toxicity, in addition to local control and improved survival ${ }^{5-6}$. While the most common side effects in RT are increased urinary frequency, burning during urination, and loss of erection, the most common rectal side effect is rectal bleeding ${ }^{7-8}$. Both acute rectal and acute urinary side effects are independent predictors of RT-induced late toxicity ${ }^{9-10}$. Lower gastrointestinal (GIS) toxicity can be observed at the rate of the dose received by the rectum in prostate RT in which ionizing radiation is applied. Lower GIS toxicity is divided into two groups: Acute toxicity (covering the treatment and the first three months after it) and late toxicity (covering the end of treatment three months and later) ${ }^{11-12}$.
Although increasing doses with RT in prostate cancer increase local control, it causes an increased dose in the surrounding normal tissue. The rectum is one of the organs most likely to be affected by increased normal tissue doses during RT. The rectum is a solid and lumen organ, and it has an inner and an outer wall. In addition to the total volume of the rectum entering the treatment area, many parameters such as the dose received by the inner and outer walls of the rectum, the neighborhood of the treated area, daily organ movement, and the condition of the organ lumen are effective in the formation of acute side effects. Many dose-volume histogram studies have examined the relationship between the doses taken by the rectum and rectal wall and the development of acute side effects ${ }^{13-18}$.

This study aimed to evaluate the organ dosevolume histogram $(\mathrm{DVH})$ parameters that affect the development of acute rectal side effects in prostate cancer patients who underwent RT with IMRT.

\section{MATERIAL AND METHODS}

Seventy-nine patients who underwent definitive or postoperative IMRT with localized and locally advanced prostate cancer diagnosis between January 2020 and December 2020 were retrospectively included in the study. Ethics committee approval of our study was received from Kartal Dr.Lütfi Kırdar City Hospital on 25.08.2021. Patients who did not complete the treatment and did not come to follow-up after RT were not taken into consideration as exclusion criteria. For reducing possible side effects, all patients were given a bowel-regulating laxative, 
simethicone preparation, during RT, starting one week before RT. Planning tomography was performed with a full bladder (200-300cc) and an emptied rectum, congested with urine 45-60 minutes after 1.5 liters of water was given to patients who had an enema and came with an empty rectum. Patients were treated by drinking 1.5 liters of water before each treatment, waiting for 45-60 minutes, urinating, and emptying their rectums. Before RT, daily images were taken from each patient, and set-up was performed online under the supervision of a doctor. Weekly acute toxicity follow-ups of the patients were carried out, and acute toxicity evaluations were continued three months after RT. Acute toxicity assessment was performed using the Radiation Therapy Oncology Group (RTOG) and European Organization for Research and Treatment of Cancer (EORTC) criteria ${ }^{12}$.

The DVH of the patients whose treatment was completed, and side effects were followed up were given as the entire rectal volume (cc) for the rectum and the most extensive rectal length included in the treatment area in the planning tomography as anterior-posterior diameter $\left(\mathrm{cm}^{3}\right)$. V75, V65, V40, V30 percentages (\%) were defined for the rectum in DVH. Maximum, minimum, median, and mean doses were evaluated for the planning target volume (PTV). Dosage schemes of 78 Gy (39fx/2Gy) were preferred for curative patients and $66 \mathrm{~Gy}(33 \mathrm{fx} / 2 \mathrm{~Gy})$ for postoperative patients. For definitive RT, PTV was created by giving a margin to the prostate site in low-risk patients. In contrast, in intermediate-risk patients, the PTV prostate site included the proximal and seminal vesicle. In highrisk patients, PTV was obtained by margining the prostate and the entire seminal vesicle, and in postoperative RT, PTV was created by giving a margin to the prostate site.

The statistical analysis was completed by transferring the data to the IBM SPSS Statistics 23 program. While evaluating the study data, frequency distribution (number, percentage) for categorical variables and descriptive statistics (mean, standard deviation) for numerical variables were given. An independent sample t-test was used to determine whether there was a difference between the two groups and whether there was a difference between more than two groups was analyzed with a one-way analysis of variance (One Way ANOVA). In addition, chi-square analysis was used to examine the relationship between categorical variables. $\mathrm{P}<0.05$ was accepted for significance.

\section{RESULTS}

Seventy-nine patients who received definitive or postoperative radiotherapy for prostate cancer in 2020 were evaluated retrospectively. Patient characteristics are summarized in Table 1. The mean age of the patients was $70(70.13 \pm 6.23)$. Definitive RT was applied to 70 patients (88.6\%), and postoperative RT was applied to 9 patients (11.4\%). The pathological diagnosis of all patients was adenocarcinoma. Distribution of patients according to Gleason scores (GS); The GS of 10 patients were $0-6(7.9 \%), 7(13.43 \%)$ of 17 patients, and 8-10 (78.67\%) of 52 patients. According to the D'amico risk classification, 14 patients $(18.2 \%)$ were in the low-risk group, 29 patients were in the medium $(37.7 \%)$, and 34 patients were in the high $(44.2 \%)$ risk group ${ }^{19}$. TNM staging system was used in which tumor characteristics $(\mathrm{T})$, lymph node $(\mathrm{N})$, and metastasis (M) status were evaluated ${ }^{20}$. According to TNM classification, 30 (38\%) patients were stage 1, 49 (62\%) patients were stage 2-3. Seventy patients received $78 \mathrm{~Gy}$ for definitive RT and $66 \mathrm{~Gy}$ for postoperative RT in 9 patients. The mean PSA values of the patients before RT were $20.16 \mathrm{ng} / \mathrm{ml}$ $( \pm 24.18)$, and the mean PSA values after RT were $0.11 \mathrm{ng} / \mathrm{ml}( \pm 0.22)$. RT was performed in 6 of 9 patients who received postoperative RT because of local recurrence in the prostate site. All patients who received postoperative RT had positive surgical margins in the pathology report.

Acute rectal toxicity was observed in 21 (26.6\%) patients after RT, Grade I (66\%) acute side effects were observed in 14 patients, and Grade II acute side effects were observed in $7(33 \%)$ patients. Treatment was given to 15 of 21 patients due to acute GIS side effects, and treatment was not interrupted in any of the patients. The percentage of rectum receiving 75 Gy was $3.49+2.65$, receiving 65 Gy was $8.5+4.53$, receiving 40 Gy was $26.68+6.9$, and receiving 30 Gy was $37.66+8.74$ in the presence of acute GI side effects and grade and DVH, respectively. There was no statistically significant difference between the volume $\left(\mathrm{cm}^{3}\right)$ and the largest diameter $(\mathrm{cm})$ measurements of the rectum ( $>0.05)$. In Table 2, acute GIS side effects and their relationship with grade and DVH parameters are summarized.

PTV was found to be Dmedian 78 Gy (72-84 Gy) for definitive RT and Dmedian 66 Gy (63-72 Gy) for postoperative RT. When the relationship between definitive or postoperative radiotherapy and occurrence of acute GIS side effects and acute GIS side effects and grade was evaluated, no statistically significant difference was found $(\mathrm{p}$ values, respectively, $\mathrm{p}=0.693, \mathrm{p}=0.307$ ) (Table 3 ). 
When the relationship between the widest rectum diameter of less than $5 \mathrm{~cm}$ in the treatment area and acute GIS side effects in planning and acute GIS side effects and grade were examined, no significant relationship was found $(\mathrm{p}=0.414$, $\mathrm{p}=0.546)$.

Table 1: Characteristics of the patients $(n=79)$

\begin{tabular}{|c|c|c|c|}
\hline \multirow{2}{*}{\multicolumn{2}{|c|}{ Age (mean + standard deviation[Mean \pm SD] $)$}} & $\mathbf{N}$ & $\%$ \\
\hline & & \multicolumn{2}{|c|}{$70,13 \pm 6,23$} \\
\hline \multirow{3}{*}{ Gleason score } & $0-6$ & 10 & 12,7 \\
\hline & 7 & 17 & 21,5 \\
\hline & $8-10$ & 52 & 65,8 \\
\hline \multirow{3}{*}{ Stage } & 1 & 30 & 38,0 \\
\hline & 2 & 39 & 49,4 \\
\hline & 3 & 10 & 12,7 \\
\hline \multicolumn{2}{|l|}{ Baseline PSA (Mean \pm SD) } & \multicolumn{2}{|c|}{$20,16 \pm 24,18$} \\
\hline \multirow{3}{*}{ Treatment risk group } & Low risk & 14 & 18,2 \\
\hline & Medium risk & 29 & 37,7 \\
\hline & High risk & 34 & 44,2 \\
\hline \multirow{2}{*}{ Hormone therapy } & No & 16 & 20,3 \\
\hline & Yes & 63 & 79,7 \\
\hline \multicolumn{2}{|c|}{ Hormone therapy duration (months) (Mean \pm SD) } & \multicolumn{2}{|c|}{$9,80 \pm 7,32$} \\
\hline \multicolumn{2}{|c|}{ Radiotherapy (dose) (Mean \pm SD) } & \multicolumn{2}{|c|}{$74,05 \pm 9,53$} \\
\hline \multicolumn{2}{|c|}{ Post-treatment PSA (Mean \pm SD)) } & \multicolumn{2}{|c|}{$0,11 \pm 0,22$} \\
\hline \multirow{2}{*}{ Recurrence place } & Prostate,VS,LN & 3 & \\
\hline & Prostate site & 6 & \\
\hline \multirow{2}{*}{ Post-surgical RT } & Adjuvant & 3 & \\
\hline & Salvage & 6 & \\
\hline \multirow{3}{*}{ Reason for adjuvant RT } & Surgical margin positivity & 9 & \\
\hline & Involvement of seminal vesicle & 1 & \\
\hline & All & 1 & \\
\hline \multicolumn{2}{|c|}{ Postoperative PSA (Mean \pm SD) } & \multicolumn{2}{|c|}{$4,70 \pm 12,29$} \\
\hline & \multicolumn{2}{|c|}{$2,86 \pm 6,06$} \\
\hline & & \multicolumn{2}{|c|}{$0,0016 \pm 0,0029$} \\
\hline \multicolumn{2}{|c|}{ PSA rare value $($ Mean \pm SD) after adjuvant or salvage $R T$} & 70 & 88,6 \\
\hline Treatment & Surgery+Salvage RT & 9 & 11,4 \\
\hline
\end{tabular}

Table 2: The relationship between acute GIS side effects and acute GIS grade and DVH parameters

\begin{tabular}{|c|c|c|c|c|c|c|}
\hline & V75 rectum \% & V65 rectum \% & V40 rectum \% & $\mathrm{V} 30$ rectum \% & $\begin{array}{c}\text { Rectum } \\
\text { volume }\left(\mathrm{cm}^{3}\right)\end{array}$ & $\begin{array}{c}\text { Largest } \\
\text { diameter }(\mathbf{c m})\end{array}$ \\
\hline & Mean \pm SD & Mean \pm SD & Mean \pm SD & Mean \pm SD & Mean \pm SD & Mean \pm SD \\
\hline \multicolumn{7}{|c|}{ Acute GIS side effects } \\
\hline No & $2.64 \pm 1.85$ & $6.62 \pm 3.62$ & $25.32 \pm 7.81$ & $38.17 \pm 12.05$ & $77.39 \pm 29.63$ & $4.53 \pm 0.79$ \\
\hline Yes & $3.49 \pm 2.69$ & $8.50 \pm 4.53$ & $26.68 \pm 6.90$ & $37.66 \pm 8.74$ & $71.62 \pm 21.29$ & $4.55 \pm 0,63$ \\
\hline \multicolumn{7}{|c|}{ Acute GIS grade } \\
\hline No & $2.64 \pm 1.85$ & $6.62 \pm 3.62$ & $25.32 \pm 7.81$ & $38.17 \pm 12.05$ & $77.39 \pm 29.63$ & $4.47 \pm 0.79$ \\
\hline Grade I & $4,19 \pm 2.91$ & $8.41 \pm 5.26$ & $26.15 \pm 7.11$ & $36.79 \pm 9.72$ & $64.97 \pm 14.52$ & $4.53 \pm 0.67$ \\
\hline $\begin{array}{l}\text { Grade } \\
\text { II }\end{array}$ & $2.22 \pm 1.81$ & $8.68 \pm 2.89$ & $27.75 \pm 6.86$ & $39.40 \pm 6.69$ & $84.91 \pm 27.28$ & $4,70 \pm 0,57$ \\
\hline
\end{tabular}


Table 3: Investigation of the relationship between acute GIS side effects and grade and treatment conditions

\begin{tabular}{|c|c|c|c|c|c|c|}
\hline & \multicolumn{4}{|c|}{ Initial Treatment } & \multirow{3}{*}{ Chi-Square/p-value } \\
\hline & & \multicolumn{2}{|c|}{ Definitive RT } & \multicolumn{2}{|c|}{ Adjuvant RT } & \\
\hline & & $\mathbf{N}$ & $\%$ & $\mathbf{N}$ & $\%$ & \\
\hline \multirow{2}{*}{$\begin{array}{l}\text { Acute GIS side } \\
\text { effects }\end{array}$} & No & 52 & 74.3 & 6 & 66.7 & \multirow{2}{*}{$0.237 / 0.693$} \\
\hline & Yes & 18 & 25.7 & 3 & 33.3 & \\
\hline \multirow{3}{*}{ Acute GIS grade } & No & 52 & 74.3 & 6 & 66.7 & \multirow{3}{*}{$2.360 / 0.307$} \\
\hline & Grade I & 13 & 18.6 & 1 & 11.1 & \\
\hline & Grade II & 5 & 7,1 & 2 & 22.2 & \\
\hline
\end{tabular}

In our study, acute rectal side effects were observed in $21(26.6 \%)$ of 79 patients, Grade I toxicity was observed in $14(66 \%)$, and Grade II toxicity in 7 $(33 \%)$ patients. Grade III-IV toxicity was not observed in any patient. Although side effects were independent of the rectum volume and the largest diameter of the rectum, the mean anterior-posterior diameter of the patients without side effects was $4.53 \mathrm{~cm}( \pm 0.79)$ and was lower than the ones with side effects. Although the relationship between the anterior-posterior diameter of the rectum and the grade of side effect was insignificant, it was observed that the anterior-posterior diameter of the rectum increased as the grade increased, respectively. Mean values were found as Grade 0; $4.47 \mathrm{~cm}$, Grade 1; $4.53 \mathrm{~cm}$, Grade 2; $4.70 \mathrm{~cm}$., respectively.

\section{DISCUSSION}

In our retrospective study of 79 patients, we aimed to examine the relationship between the occurrence of acute GI side effects and DVH parameters. Increased bowel activity, diarrhea, severe rectal bleeding, pain, and fistula can be seen as GIS symptoms in prostate RT. While the GIS responds to RT with inflammation in the acute side-effect period, it manifests itself with sclerosis and fibrosis in the gastrointestinal tract during the posttreatment chronic side-effect period ${ }^{22}$. In their study, Campostrian et al. pathologically confirmed that the occurrence of acute toxicity is directly related to the occurrence of late toxicity, independent of the RT technique ${ }^{23}$. In addition, studies have shown that RT and acute GIS toxicity are associated with persistent and late GIS toxicity 24-25. This situation has made it even more critical to determine the parameters that affect acute GIS toxicity. It has been observed that GIS side effects have decreased with the use of modern RT techniques today and the increase in the use of IMRT $^{26}$.

Similarly, some non-randomized studies have shown that IGRT, like IMRT, reduces radiation- related side effects ${ }^{27-28}$. However, the necessity of using a marker for IGRT appears to be the most significant limiting step in applying this technique ${ }^{29-30}$. Markers placed in IGRT are essential to minimize the difference in organ movement between the fractions and follow the organ correctly ${ }^{31}$. In IMRT, on the other hand, it is tried to prevent normal tissue dose increases due to organ movement by giving the required set-up margin to the target volume.

Although the side effects of prostate RT can be reduced by techniques that protect normal tissue well, such as IGRT and IMRT, it has been shown that DVH parameters are also effective in the development of acute GIS toxicity. In our study, although we examined the relationship between rectal doses, rectal volume $\left(\mathrm{cm}^{3}\right)$, and anteriorposterior rectum diameter on acute GIS side effects, we found that rectal diameter tended to increase from Grade 0 to Grade 2, but it was not statistically significant. Contrary to our study, in many studies, it was shown that the doses taken by the anterior wall of the rectum instead of the entire rectal volume for the formation of rectal side effects were associated with the occurrence of side effects. The percentage and specific doses of the anterior wall of the rectum were evaluated in DVH 13-18.

In recent years, while dose-escalation studies in prostate RT show an increase in survival, it has been shown that it also causes an increase in side effects. In the GETUG-06 study comparing 70 Gy and $80 \mathrm{~Gy}$, the rates of acute side effects in the second month after treatment were shown as $43 \%$ and $48 \%$, respectively ${ }^{32}$. In our study, the rate of acute GI side effects in the first three months at the end of the treatment was $26.6 \%$ in our patients who were treated with a dose of $78 \mathrm{~Gy}(2 \mathrm{~Gy} * 39 \mathrm{fx})$ for definitive RT and 66 Gy (2Gy*33fx) for postoperative RT. In addition, while Grade III and IV toxicity was not observed in any patient, grade I toxicity was observed in 14 patients and Grade II toxicity in 7 patients. In their study of 743 patients, 
Skwarchuk et al. emphasized that increased prostate RT doses were also associated with late rectal bleeding in patients with acute rectal toxicity 33. Our study could not evaluate late rectal bleeding, as there was not enough follow-up time for the patients treated in 2020 .

In another study in which 1132 prostate cancer patients were evaluated, it was emphasized that the rectal dose-volume limit for rectal bleeding is V75 Gy $<5 \%$, and a V70 Gy $<15-20 \%$ in postoperative patients can reduce rectal bleeding ${ }^{34}$. In our study, grade I acute GIS toxicity was V75 Gy on average $4.19 \%$, and Grade 2 toxicity was $2.22 \%$. On the other hand, in another study performed with 3DCRT and applied 74 Gy, Grade III and Grade IV acute GIS toxicity was never encountered. Acute rectal toxicity Grade II was found with a rate of $5.8 \%$, and this study emphasized that the percentage of V70 is a reliable predictor for late rectal toxicity ${ }^{35}$.

In the studies of Droge et al. in 40 patients treated with hypofractionated IMRT ( $75 \mathrm{~Gy} / 25 \mathrm{fx}$ ), acute GI toxicity was observed at a rate of $12.9 \%$, and as in our study, no relationship was found between DVH parameters and acute toxicities ${ }^{36}$. In the study of Kapoor R et al., similar to our study, Grade II and higher acute toxicity was not observed; similarly, Grade I 20\%, Grade II $8 \%$ acute GIS toxicity was found, and no significant relationship was found between DVH and occurrence of acute side effects ${ }^{37}$. In conclusion, in contrast to our study, higher rates of acute GIS toxicity were reported in many studies in the literature ${ }^{10,33-36,38}$.

The retrospective nature of our study is one of the most significant limitations. Other limitations of the study can be listed as the fact that it covers all primary and postoperative RT patients with low, medium, and high risk. The number of groups differs from each other. It is thought that prospective studies in which the whole rectum and the rectal wall are specifically examined, and the acute and late side effects of other organs except the rectum are evaluated will be more helpful in assessing this issue.

\section{CONCLUSION}

Prostate cancer treatment with IMRT has low rates of acute GIS toxicity. Although studies show the relationship between acute GIS toxicity in prostate cancer radiotherapy and rectal volume and diameter in DVH, our study found that acute GI side effects were independent of the rectum's volume, diameter, and dosimetric parameters.

\section{REFERENCES}

1. Quaglia A, Parody S, Grosclaude P, MartinezGarcia C, Coebergh JW, Vercelli M. Differences in the epidemic rise and decrease of prostate cancer among geographical areas in Southern Europe: an analysis of differential trends in incidence and mortality in France, Italy and Spain. Eur J Cancer, 39: 654-665, 2003.

2. Hanks GE, Hanlon AL, Schultheiss TE, et al. Dose escalation with 3D conformal treatment: five-year outcome, treatment optimization, and future directions. Int J Radiat Oncol Biol Phys, 41: 501-510, 1998.

3. Zietman AL, Coen JJ, Dallow KC, Shipley WU. The treatment of prostate cancer by conventional radiation therapy: an analysis of long-term outcome. Int $\mathbf{J}$ Radiat Oncol Biol Phys, 32: 287-292, 1995.

4. Morris D, Emami B, Mauch PM, et al. Evidence-based review of three-dimensional conformal radiotherapy for localized prostate cancer: an ASTRO outcomes initiative. Int J Radiat Oncol Biol Phys, 62: 3-19, 2005.

5. Peeters ST, Heemsbergen WD, Koper PC, et al. (2006) Dose-response in radiotherapy for localized prostate cancer: results of the Dutch multicenter randomized phase III trial comparing 68Gy of radiotherapy with $78 \mathrm{~Gy}$. J Clin Oncol 24:1990-1996

6. Kuban DA, Tucker SL, Dong L, et al. (2008) Long-term results of the M. D. Anderson randomized dose-escalation trial for prostate cancer. Int J Radiat Oncol Biol Phys 70:67-74

7. Fransson P, Lund JA, Damber JE, et al. Quality of life in patients with locally advanced prostate cancer given endocrine treatment with or without radiotherapy: 4-year follow-up of SPCG-7/SFUO- 3, an open-label, randomised, phase III trial. Lancet Oncol 2009;10:370-80.

8. Lund JA. Late effects to the rectum and anus in prostate cancer patients randomized to hormonal therapy versus hormonal therapy plus radiotherapy. J Gastroenterol Hepatol 2013;2.

9. Jereczek-Fossa BA, Zerini D, Fodor C, et al. Correlation between acute and late toxicity in 973 prostate cancer patients treated with threedimensional conformal external beam radiotherapy. Int $\mathbf{J}$ Radiat Oncol Biol Phys 2010;78:26-34.

10. Heemsbergen WD, Peeters ST, Koper PC, Hoogeman MS, Lebesque JV. Acute and late 
gastrointestinal toxicity after radiotherapy in prostate cancer patients: Consequential late damage. Int $\mathbf{J}$ Radiat Oncol Biol Phys 2006;66:3-10.

11. A. Trotti, A. D. Colevas, A. Setser, et al., "CTCAE v3.0: development of a comprehensive grading system for the adverse effects of cancer treatment," Seminars in Radiation Oncology, vol. 13, no. 3, pp. 176181, 2003.

12. D. Cox, J. Stetz, and T. F. Pajak, "Toxicity criteria of the radiation therapy oncology group (RTOG) and the European organization for research and treatment of cancer (RTOG)," International Journal of Radiation Oncology, Biology, Physics, vol. 31, no. 5, pp. 1341-1346, 1995.

13. Koper, P.C, Heemsbergen, W.D., Hoogeman, M.S., et al. Impact of volume and location of irradiated rectum Wall on rectal blood loss after radiotherapy of prostate cancer. Int. J. Radiat. Oncol. Biol. Phys. 58:1072-82; 2004.

14. Peeters, S.T., Hoogeman, M.S., Heemsbergen, W.D., et al. volume and hormonal effects for acute side effects of rectum and bladder during conformal radiotherapy for prostate cancer. Int. J. Radiat. Oncol. Biol. Phys. 63:1142-52; 2005.

15. Marzi, S., Arcangeli, G., Saracino, B., et al. Relationships between rectal wall dose-volume constraints and radiobiologic indices of toxicity for patients with prostate cancer. Int. J. Radiat. Oncol. Biol. Phys. 68:41-9; 2007.

16. Tucker, S.L., Dong, L., Cheung, R., et al. Comparison of rectal dose-wall histogram versus dose-volume histogram for modeling the incidence of late rectal bleeding after radiotherapy. Int.J. Radiat. Oncol. Biol. Phys. 60:1589-601;2004.

17. Jackson, A., Skwarchuk, M.W., Zelefsky, M.J., et al. Late rectal bleeding after conformal radiotherapy of prostate cancer. II.Volume effects and dose-volume histograms. Int. J. Radiat. Oncol. Biol. Phys. 49:685-98; 2001.

18. Vargas, C., Martinez, A., Kestin, L.L., et al. Dose-volume analysis of predictors for chronic rectal toxicity after treatment of prostate cancer with adaptive image-guided radiotherapy. Int. J. Radiat. Oncol. Biol. Phys. 62:1297-308; 2005.

19. Preisser F, Cooperberg MR, Crook J, et al. Intermediate-risk Prostate Cancer: Stratification and Management. Eur Urol Oncol. 2020 Jun;3(3):270-280. doi: 10.1016/j.euo.2020.03.002. Epub 2020 Apr 14.
20. Varma M, Cochlin D, Delahunt B, et al. TNM clinical staging of prostate cancer: issues and solutions. BJU Int. 2019 Mar;123(3):382-384. doi: 10.1111/bju.14589. Epub 2018 Oct 31. PMID: 30315677.

21. Peto R, Pike MC, Armitage P. Design and analysis of randomized clinical trials requiring prolonged observation of each patient. II. Analysis and examples. $\mathrm{Br} \mathbf{J}$ Cancer. 1977;35:1-39.

22. 22- P. P. Tagkalidis and J. J. Tjandra, "Chronic radiation proctitis," ANZ Journal of Surgery, vol. 71, no. 4, pp. 230-237, 2001.

23. S. Kang, M. Chun, Y.-M. Jin et al., "A rat model for radiation induced proctitis," Journal of Korean Medical Science, vol. 15, no. 6, pp. 682-689, 2000.

24. W. D" orr and J. H.Hendry, "Consequential late effects in normal tissues," Radiotherapy and Oncology, vol. 61, no. 3, pp. 223-231,2001

25. Peach MS, Showalter TN, Ohri N. Systematic Review of the Relationship between Acute and Late Gastrointestinal Toxicity after Radiotherapy for Prostate Cancer. Prostate Cancer. 2015;2015:624736. doi: 10.1155/2015/624736. Epub 2015 Nov 30. PMID: 26697225; PMCID: PMC4677238.

26. N. Ohri, A. P. Dicker, and T. N. Showalter, "Late toxicity rates following definitive radiotherapy for prostate cancer," Canadian Journal of Urology, vol. 19, no. 4, pp. 63736380, 2012

27. Sveistrup J, Af Rosenschold PM, Deasy JO, et al. Improvement in toxicity in high risk prostate cancer patients treated with image-guided intensity-modulated radiotherapy compared to 3D conformal radiotherapy without daily image guidance. Radiat Oncol 2014;9:44.

28. Zelefsky MJ, Kollmeier M, Cox B, et al. Improved clinical outcomes with high-dose image guided radiotherapy compared with nonIGRT for the treatment of clinically localized prostate cancer. Int J Radiat Oncol Biol Phys 2012;84:125-9.

29. Jorgo K, Ágoston P, Major T, et al. (2017) Trans-perineal gold marker implantation for image-guided external beam radiotherapy of prostate cancer: a single institution, prospective study. Strahlenther Onkol 193:452-458

30. Wust P, Joswig M, Graf R, et al. (2017) Dosimetric implications of inter-and intrafractional prostate positioning errors during tomotherapy: comparison of gold 
marker-based registrations with native MVCT. Strahlenther Onkol 193:700-706

31. Gauthier, I., Carrier, J.F., Beliveau-Nadeau, D., et al. Dosimetric impact and theoretical clinical benefits of fiducial markers for döşe escalated prostate cancer radiation treatment. Int. J. Radiat. Oncol. Biol. Phys. 74:1128-33; 2009

32. Beckendorf V, Guerif S, Le PE, et al. 70 Gy versus 80 Gy in localized prostate cancer: 5year results of GETUG 06 randomized trial. Int J Radiat Oncol Biol Phys 2011;80:1056-63.

33. Skwarchuk MW, Jackson A, Zelefsky MJ, et al. Late rectal toxicity after conformal radiotherapy of prostate cancer (I): Multivariate analysis and dose-response. Int J Radiat Oncol Biol Phys 2000;47:103-13.

34. Fellin G, Fiorino C, Rancati T, et al. Clinical and dosimetric predictors of late rectal toxicity after conformal radiation for localized prostate cancer: Results of a large multicenter observational study. Radiother Oncol 2009;93:197-202.

35. Ballare A, Di Salvo M, Loi G, Ferrari G, Beldi
D, Krengli M. Conformal radiotherapy of clinically localized prostate cancer: Analysis of rectal and urinary toxicity and correlation with dose-volume parameters. Tumori 2009;95:160-8.

36. Drodge CS, Boychak O, Patel S, et al. Acute toxicity of hypofractionated intensity-modulated radiotherapy for prostate cancer. Curr Oncol 2015;22:e76-84.

37. Kapoor R, Bansal A, Kumar N, Oinam AS. Dosimetric correlation of acute and late toxicities in high-risk prostate cancer patients treated with three-dimensional conformal radiotherapy followed by intensity modulated radiotherapy boost. Indian J Urol. 2016 JulSep;32(3):210-5. doi: 10.4103/09701591.185098. PMID: 27555679; PMCID: PMC4970392.

38. Storey MR, Pollack A, Zagars G, Smith L, Antolak J, Rosen I. Complications from radiotherapy dose escalation in prostate cancer: Preliminary results of a randomized trial. Int $\mathrm{J}$ Radiat Oncol Biol Phys 2000;48:635-42. 